\title{
Possibilities of Using Fractal Geometry to Identify Areas at Risk of Their Shoreline Becoming Outdated**
}

\section{Introduction}

According to the statutory definition [9], the register of land and buildings is a unified for the country and, what is important, regularly updated, set of information on the and, buildings and premises, as well as on their owners and possessors. The purpose of this update is to replace the information which is inconsistent with the factual or legal status with valid data [8].

Discrepancies in the cadastral database result from numerous factors, including natural ones. The elements which are the most at risk of outdatedness are, of course, those of the cadastral database whose attributes depend on the natural objects, characterized by high volatility in time, such as surface water.

Keeping the existing database of the register of land and buildings updated is one of the tasks of the body by which this database is run. This means that the information contained in the cadastral database must be consistent with the documents and source materials available for the body it is run by.

The update of the cadastral survey is performed upon the request, or ex officio, through the introduction of the documented changes to the cadastral database. In addition, however, periodic verification of the cadastral data is required, in terms of compliance of the content of the cadastral map with the factual status in the field. It is carried out in each cadastral unit, at least once every 15 years. Such verification covers the whole areas of the cadastral units.

While conducting periodic verification of the cadastral data, special attention should be paid to these sites and cadastral objects which, as a result of the passage of time, will always be subject to obsolescence. Those that are exposed to the action of surface water are especially critical. However, it cannot be stated arbitrarily that everything in their vicinity will be subject to changes. This is particularly important

\footnotetext{
* AGH University of Science and Technology, Faculty of Mining Surveying and Environmental Engineering, Department of Geomatics, Krakow, Poland

** This work has been carried out within scientific research program no. 15.11.150.289/2015
} 
due to the fact that only until the shoreline is determined according to the principles set forth in [10], the course of the boundaries of record parcels between the land forming their bottoms and shores and the land adjacent to them may be included in the records using the data determined by the results of the detailed measurements, without conducting long administrative proceedings.

The aim of the research studies is to identify those areas where the changes in the configuration of cadastral boundaries as a result of the changes in the shorelines will be most likely. Due to the fact that shorelines are regarded as one of the examples of natural fractals, their analysis could turn out to be a tool for their identification. The assumption that one of the characteristics of fractals is their self-similarity was at the core of the work. If the analyzed fragment proved to be a fractal, it could turn out that the changes occur in a way which could be attempted, at least partially, to be described mathematically.

\section{Fundamentals of Fractal Geometry}

The history of fractal geometry is not too long and goes back to the end of the 1970s. At that time, Benoit B. Mandelbrot began to publish his works. Many widely known fractals, previously characterized in the literature (such as Cantor set, Koch curve or Sierpinski carpet), were derived from classical mathematics. These are, however, specific exceptions to the theorems of the classical Euclidean geometry, not the foundation of a new field of mathematics [6].

Despite the huge interest in fractals expressed by researchers from various disciplines, their strict mathematical definition has not been developed until this day. Currently, fractals are referred to as sets, for which the Hausdorff-Besicovitch dimension (the so-called fractal dimension) is greater than the topological dimension, and is not an integer [5].

Self-similarity is considered to be a characteristic feature of fractals, which is exhibited by the shape of the entire object (a set) being similar to its fragment.

Fractal structures can not always be studied using scientific methods. However, there are simple empirical methods which allow for their identification by determining the fractal dimension.

The number $\mathrm{D}$ is called the fractal dimension of a set of points $\mathrm{A}$ in the n-dimensional space $\mathrm{Rn}$ when it satisfies the relationship:

$$
\lim _{s \rightarrow 0} N(s) \approx s^{-D}
$$

where $N(s)$ is the number of spheres with the diameter s which are needed to cover the set $\mathrm{A}$.

Fractal dimension can be defined in several ways. It depends on the type of an object whose fractal dimension is being determined. And so, for strictly self-similar 
objects, the dimension of self-similarity can be determined. The determination of this dimension is possible due to the relationship that exists between the reduction coefficient and the number of the small-scale objects that make up the larger-scale object. This relationship is expressed by the formula:

$$
a=\frac{1}{s^{D_{s}}}
$$

where:

$$
\begin{gathered}
a-\text { number of parts, } \\
s-\text { reduction coefficient, } \\
D_{s}-\text { dimension of self-similarity. }
\end{gathered}
$$

This means that the dimension of the self-similarity can be determined using the following formula:

$$
D_{s}=\frac{\log a}{\log \frac{1}{S}}
$$

For linear objects, the compass dimension is determined. It is based on the power-law affecting the length of the measured curve, depending on the spacing of the compass which this curve was measured with. The compass dimension is defined by the formula:

$$
D_{c}=1+d
$$

where $d$ is the slope of the graph of the logarithms of the measured length depending on the measuring accuracy, or the slope of the graph of the logarithms of the number of steps needed to cover the curve, relative to the spacing of the compass which this curve is measured with.

The box-counting dimension, however, should be recognized as the most universal one. The dimension of any kind of an object can be determined using it. Its determination involves placing the studied structure on a regular grid of squares with the mesh size s, and then counting these "boxes" which contain fragments of the analyzed structure $N(s)$. The measurement is performed several times, each time reducing the size of $s$. The obtained pairs of numbers: $s$ and $N(s)$ are placed on a logarithmic graph. The number, which is the slope of the straight line fitted into these points, is the box-counting dimension of the analyzed structure.

\section{The Shoreline as a Fractal}

The shoreline is the flagship object of nature, which has been presented in the literature [2-4] as the so-called random fractal (natural). When compared with the 
fractals which are generated mathematically, random fractals are different in a way that [7]:

- they are self-similar only statistically, which means that their fragments exhibit the same statistical properties at different scales;

- when analyzing an object at smaller and smaller scales (with a larger denominator), they may lose their self-similarity.

The verification, whether at the level of detail of the cadastral database, the rivers retain their fractal properties, and whether these properties could be used to identify areas at risk of the shoreline becoming outdated, was commenced with large-scale analyses. From the National Geodetic and Cartographic Documentation Center, a layer of General Geographic Database containing the river network of the Małopolska province, was collected (Fig. 1a). Then, its box-counting dimension was determined (Fig. 1b, Fig. 2, Tab. 1).

a)

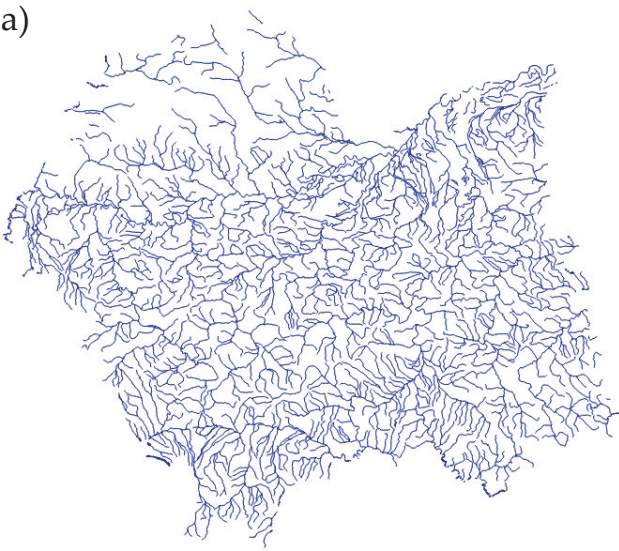

b)

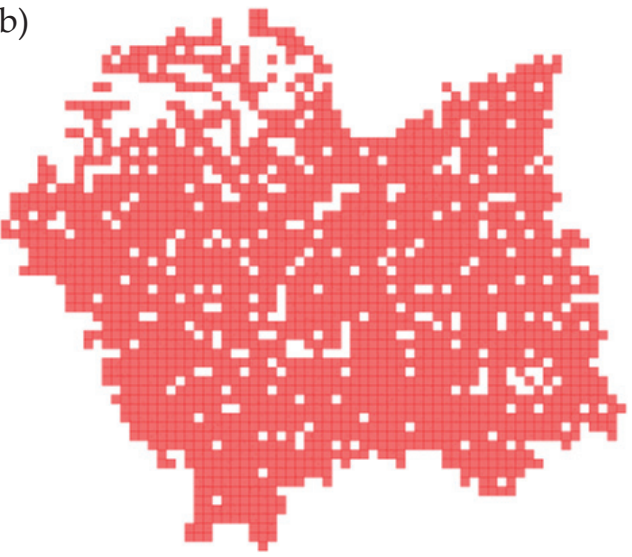

Fig. 1. The river network of the Małopolska province (a); covering the river network of the Małopolska province with a grid of a mesh size $s=2500 \mathrm{~m} \mathrm{(b)}$

Source: a) National Geodetic and Cartographic Documentation Center - General Geographic Database; b) own study

Table 1. The box-counting dimension of the river network of the Małopolska province

\begin{tabular}{||c|c|c|c||}
\hline \hline No. & Grid dimension $s[\mathrm{~m}]$ & Number of “boxes" containing the object $N(s)$ & Box-counting dimension \\
\hline \hline 1 & 200 & 8758 & \\
\hline 2 & 500 & 6457 & \multirow{2}{*}{0.55} \\
\hline 3 & 1000 & 4759 & \\
\hline 4 & 1500 & 3583 & \\
\hline 5 & 2000 & 2702 & \\
\hline 6 & 2500 & 2046 & \\
\hline
\end{tabular}




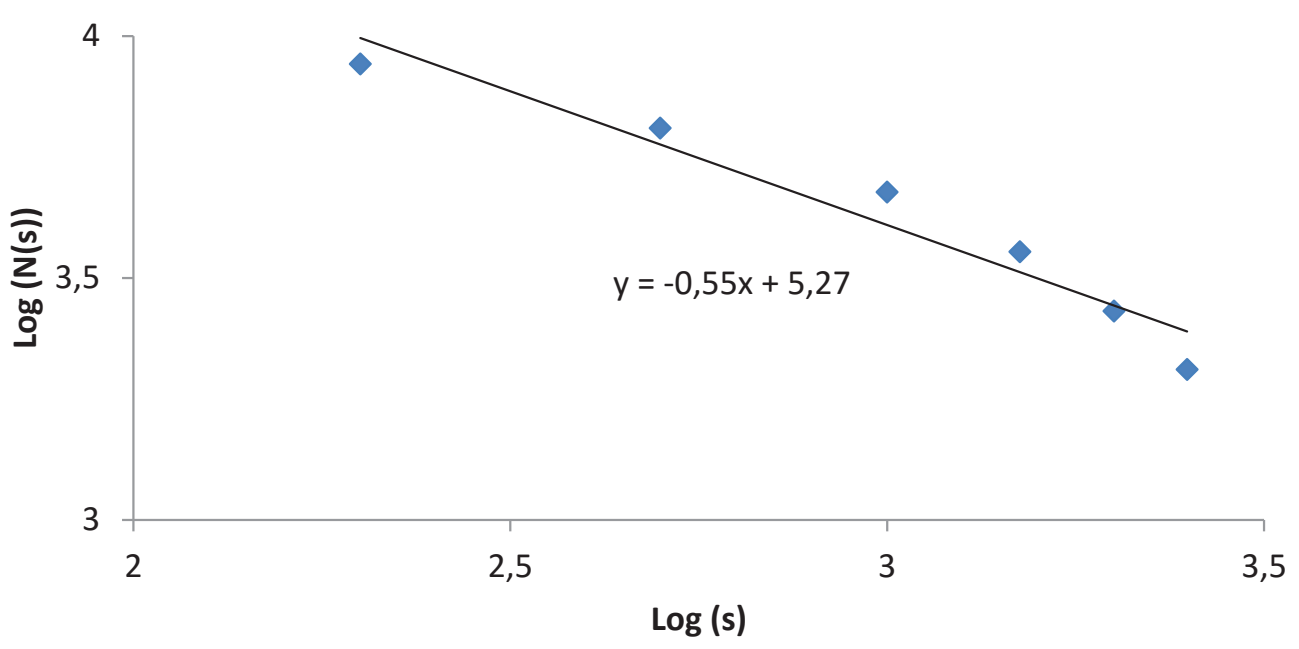

Fig. 2. The box-counting dimension of the river network of the Małopolska province

Due to the fact that the box-counting dimension of the river network of the Małopolska province is not an integer, it may be expected that, with every enlargement of the scale, its parts should exhibit some similarity to the whole, and thus also have a box-counting dimension different from the integer value. Over a 13-kilometer section of the bank of the Vistula River near Krakow was analyzed (Fig. 3).

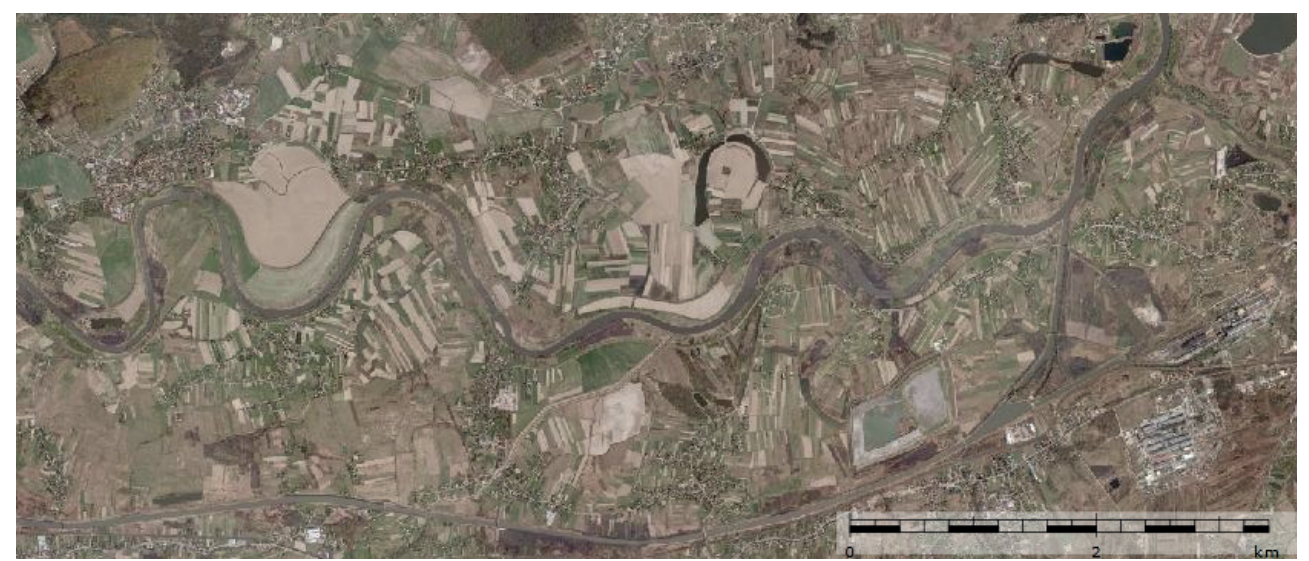

Fig. 3. The analyzed section of the Vistula River near Krakow

Source: www.geoportal.gov.pl

The course of the analyzed section of the river was determined based on the documentation from the District Geodetic and Cartographic Documentation Center in Krakow. 
As it was verified in [1], the water was breaking into the south bank of the Vistula River in larger extent. Therefore, it was decided to determine the box-counting dimension for this one bank only. Figure 4 illustrates its coverage with a grid of different mesh sizes.

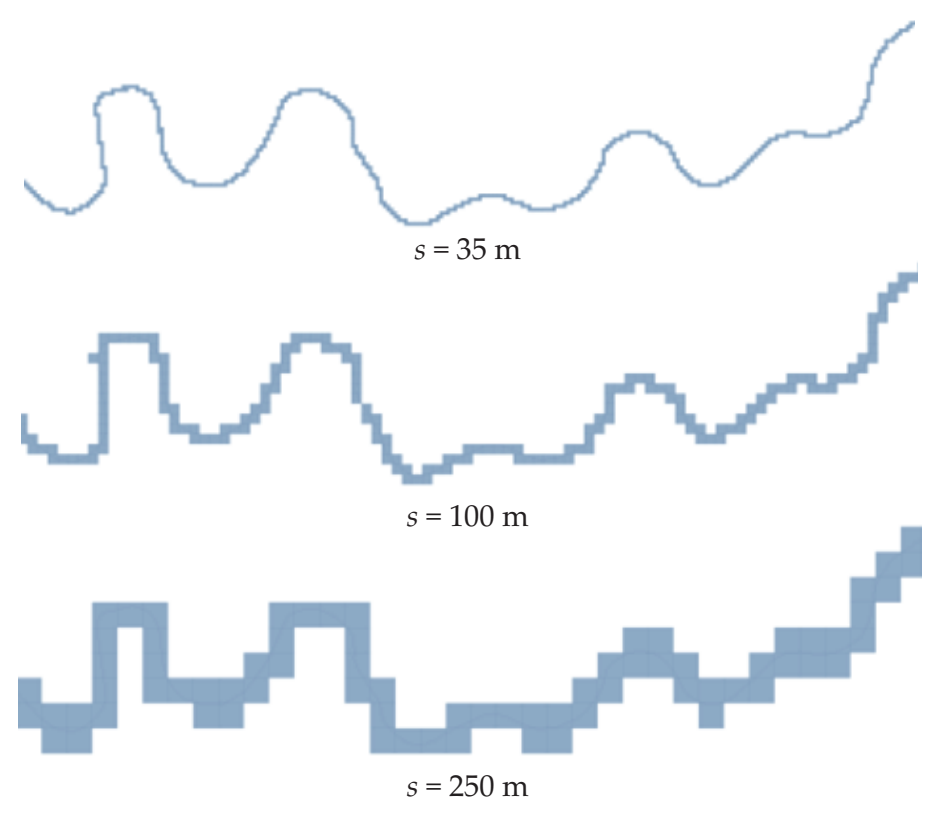

Fig. 4. The box-counting dimension of a section of the south bank of the Vistula River near Krakow

The values obtained for the "boxes" of various sizes have been summarized in Table 2, and the box-counting dimension of the right bank of the Vistula River near Krakow was determined from the graph in Figure 5.

Table 2. The box-counting dimension of the right bank of the Vistula River near Krakow

\begin{tabular}{||c|c|c|c||}
\hline No. & Grid dimension $s[\mathrm{~m}]$ & Number of “boxes” containing the object $N(s)$ & Box-counting dimension \\
\hline \hline 1 & 2 & 7646 & \\
\hline 2 & 5 & 3344 & \\
\hline 3 & 10 & 1718 & \\
\hline 4 & 20 & 858 & \multirow{2}{*}{0.97} \\
\hline 5 & 35 & 503 & \\
\hline 6 & 60 & 291 & \\
\hline 7 & 100 & 177 & \\
\hline 8 & 150 & 120 & \\
\hline 9 & 250 & 73 & \\
\hline
\end{tabular}




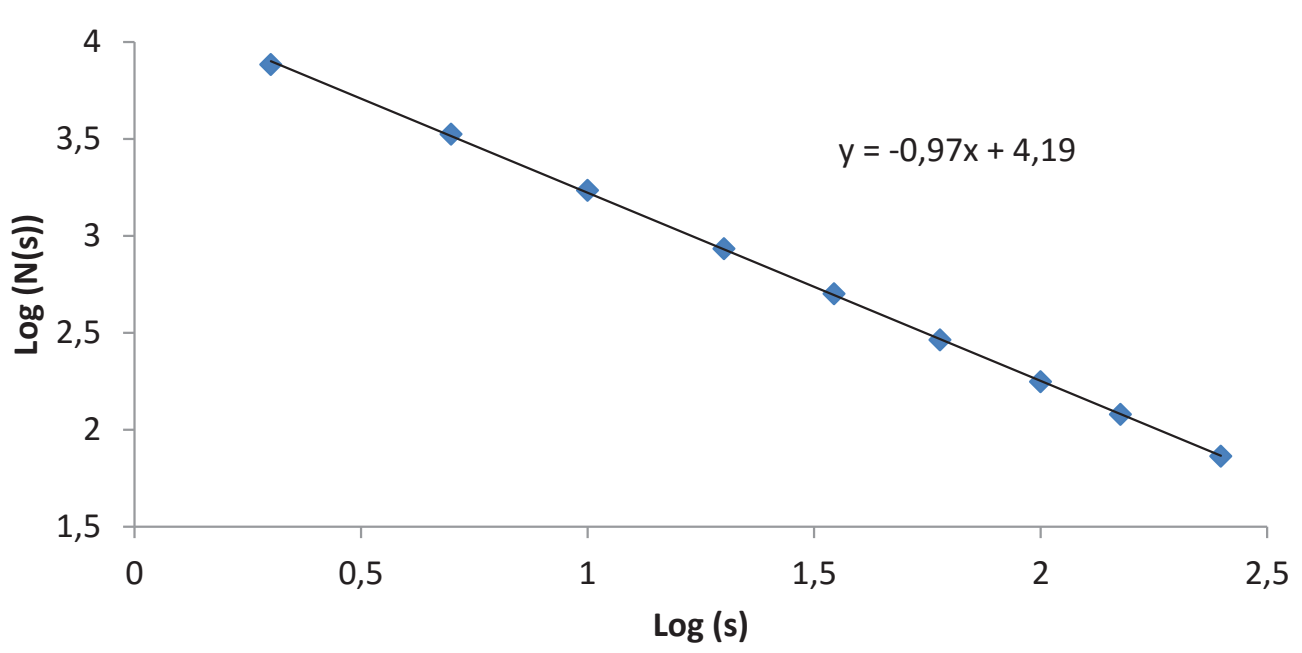

Fig. 5. The box-counting dimension of the right bank of the Vistula River near Krakow

The box-counting dimension of the right bank of the Vistula River near Krakow is close to unity. This means that, in such a large approximation, it is no longer a fractal.

\section{Detection of the Outdated Shoreline}

Since the analyzed shoreline did not exhibit fractal properties at this level of detail, it was studied whether these applied to the spatial arrangement of the fragments of cadastral parcels which had been eroded and carried away by the flowing water. Their arrangement is illustrated in Figure 6.

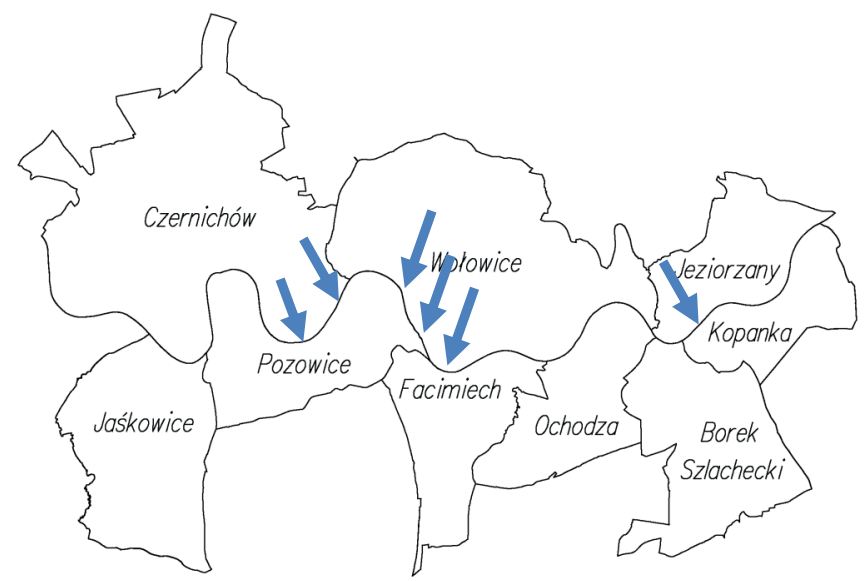

Fig. 6. Location of cadastral parcels invaded by the flowing water 
Similarly, as in the previous cases, the values obtained for the "boxes" of various sizes have been summarized in Table 3. The box-counting dimension of the arrangement of the Vistula River cuts into land was determined from the graph in Figure 7.

Table 3. The box-counting dimension of the arrangement of the Vistula River cuts into land

\begin{tabular}{|c|c|c|c|}
\hline No. & Grid dimension $s[\mathrm{~m}]$ & Number of "boxes" containing the object $N(s)$ & Box-counting dimension \\
\hline 1 & 2 & 1925 & \\
\hline 2 & 5 & 498 & \multirow{2}{*}{1.21} \\
\hline 3 & 10 & 210 & \\
\hline 4 & 20 & 98 & \\
\hline 5 & 35 & 61 & \\
\hline
\end{tabular}

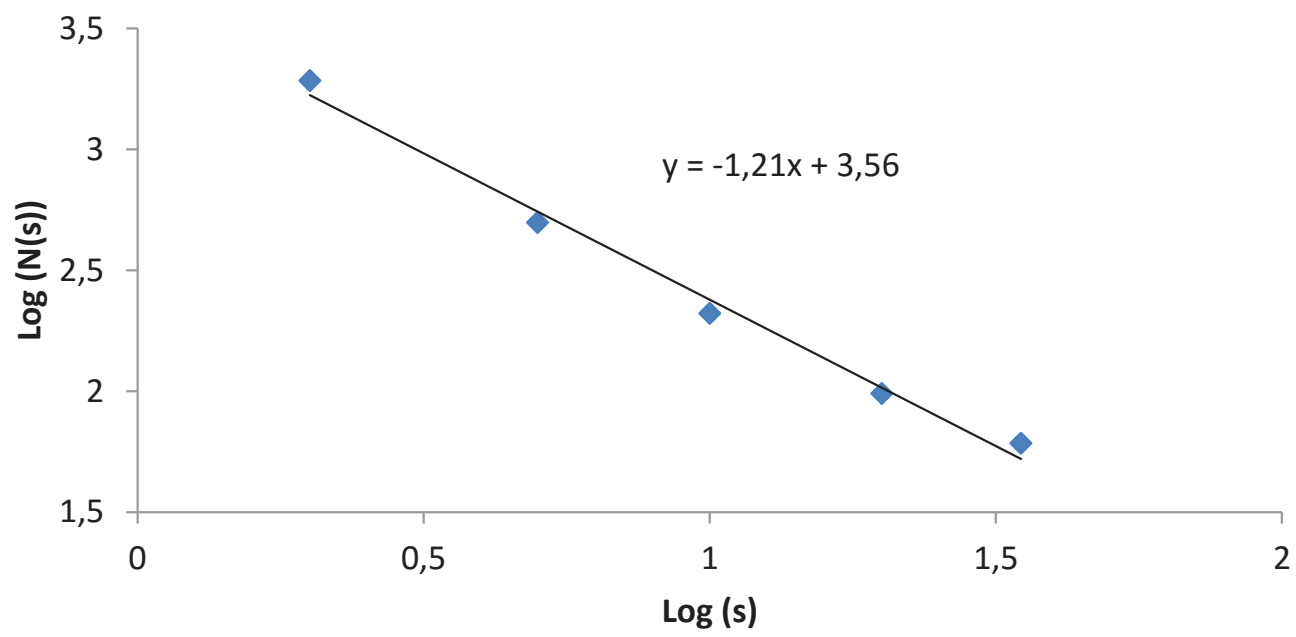

Fig. 7. The box-counting dimension of the arrangement of the Vistula River cuts into land

The obtained value (1.21) suggests that fragments of cadastral parcels invaded by the water exhibit some self-similarity.

\section{Conclusions}

In conclusion, it should be noted that:

1. The conducted analyses are only the springboard for further research, and they may not form the basis for the inference about the effectiveness of the proposed method for identification of the areas at risk of their shoreline becoming outdated. 
2. The studies have confirmed the thesis that there is a possibility of losing self-similarity by the natural fractals in small scales.

3. The box-counting dimension is not the best way to determine the fractal dimension of a shoreline. However, it was used because two types of natural objects were compared: the river network and the shoreline.

\section{References}

[1] Bieda A., Parzych P.: Wptyw zmian linii brzegowych na konfiguracje granic ewidencyjnych. Studia i Materiały Towarzystwa Naukowego Nieruchomości, vol. 20 (4), 2012, pp. 67-76.

[2] Dai Z.J., Li C.C., Zhang Q.L.: Fractal analysis of shoreline patterns for crenulate-bay beaches, Southern China. Estuarine. Coastal and Shelf Science, vol. 61 (1), 2004, pp. 65-71.

[3] Jiang J., Plotnickm R.E.: Fractal analysis of the complexity of United States coastlines. Mathematical Geology, vol. 30 (5), 1998, pp. 535-546.

[4] Mandelbrot B.: How Long Is the Coast of Britain? Statistical Self-Similarity and Fractional Dimension. Science. New Series, no. 3775, 1967, pp. 636-638.

[5] Mandelbrot B.B.: Fractals and Chaos: The Mandelbrot Set and Beyond. Springer-Verlag, New York 2004.

[6] Peitgen H.-O., Jürgens H., Saup D.: Fraktale. Granice chaosu. WN PWN, Warszawa 2002.

[7] Ratajczak W: Metodologiczne aspekty fraktalnego modelowania rzeczywistości. UAM, Poznań 1998.

[8] Rozporzadzenie Ministra Rozwoju Regionalnego i Budownictwa z dnia 29 marca 2001 r. w sprawie ewidencji gruntów i budynków. Tekst jednolity: 27.02.2015, Dz.U. 2015, poz. 542 z późn. zm. [consolidated text: 27.02.2015, Journal of Laws 2015, item 542 with amendments].

[9] Ustawa z dnia 17 maja 1989 r. - Prawo geodezyjne i kartograficzne. Tekst jednolity: 8.03.2015, Dz.U. 2015, poz. 520 z późn. zm. [consolidated text: 8.03.2015, Journal of Laws 2015, item 520 with amendments].

[10] Ustawa z dnia 18 lipca 2001 r. - Prawo wodne. Tekst jednolity: 27.02.2015, Dz.U. 2015, poz. 469 z późn. zm. [consolidated text: 27.02.2015, Journal of Laws 2015, item 469 with amendments]. 